J. Reprod. Fert. (1966) 11, 73-84

\title{
THE INFLUENCE OF THE ROUTE OF ADMINISTRATION OF 1-ALPHA-METHYLALLYLTHIO- CARBAMOYL-2-METHYLTHIOCARBAMOYLHYDRA- ZINE ON REPRODUCTION IN RATS AND MICE
}

\author{
F. EUGENE HARRINGTON AND WAYNE H. LINKENHEIMER \\ Agricultural Division, American Cyanamid Company, \\ Princetown, New Fersey, U.S.A.
}

(Received 30th April 1965)

\begin{abstract}
Summary. One hundred and eighty-six mature nonparous CFN rats and ninety-six mature nonparous Taconic mice were used to determine the effect of compound I.C.I. 33,828 on reproduction when administered by three different routes at dose rates of 8,16 and $32 \mathrm{mg} / \mathrm{kg}$. Females of both species were treated with the compound for 4 days before adding known fertile males to the female cages. Treatment continued for 11 days. Daily observations were made for spermatozoa in the vaginal smears of rats and for vaginal plugs in mice during this time. On the morning of the 12th day, treatment was stopped and the males were removed from the cages.

The results showed that Compound I.C.I. 33,828 at 16 and $32 \mathrm{mg} / \mathrm{kg}$ was an effective antifertility agent in rats, regardless of the route of administration. In mice, it was not an effective antifertility agent when injected subcutaneously; however, it was an effective antifertility agent in mice when added to the diet at $32 \mathrm{mg} / \mathrm{kg}$, but only partially effective at the 8 and $16 \mathrm{mg} / \mathrm{kg}$ levels.
\end{abstract}

\section{INTRODUCTION}

Evidence has accumulated that 1-alpha-methylallylthiocarbamoyl-2-methylthiocarbamoylhydrazine (Compound I.C.I. 33,828) has a marked effect on fertility in some species, but not in others. Paget, Walpole \& Richardson (1961), working with several species, concluded provisionally that it had either a direct effect on the production of gonadotrophins by the pituitary, or an effect on the presumed hypothalamic control of that function. Brown (1963) concluded that it specifically inhibited formation of the gonadotrophins by the anterior pituitary gland. Edgren \& Peterson (1964) found that it would prevent compensatory hypertrophy in hemicastrated rats when treatment was initiated on the day of castration and continued for 15 days. However, they were unable to determine whether it specifically blocked FSH or LH. 
Reversible inhibition of pituitary gonadotrophic function was reported in rats, dogs and monkeys, but not in mice, guinea-pigs, rabbits or horses (Paget et al., 1961). Bell, Brown, Fotherby \& Loraine (1962) and Mears (1962) presented contradictory information on the effect of Compound I.C.I. 33,828 on menstruation, but both studies reported suppression of ovulation in women. France \& Pincus (1964) reported that it did not prevent the induction of ovulation by gonadotrophin in intact immature rats.

Paget et al. (1961) reported that oral doses as low as $20 \mathrm{mg} / \mathrm{kg}$ interrupted the oestrous cycles in rats and that normal cycles were restored within 2 to 3 days after withdrawal. The same authors reported that oral doses of $100 \mathrm{mg} / \mathrm{kg}$ for 3 consecutive days prevented birth of offspring in rats; they concluded that the effect in early pregnancy was probably due to failure of implantation and, in the later stages, to foetal death and resorption. Harper (1964) more recently presented evidence that oral doses of $100 \mathrm{mg} / \mathrm{kg}$ on 3 successive days did not inhibit implantation in the rat when treatment was initiated on Days -1, 0, 1, 3 and 4 of pregnancy. Treatment started on Day 2 of pregnancy did inhibit implantation.

Results of preliminary investigations with the rat and mouse in this laboratory suggested that the response of these species to Compound I.C.I. 33,828 may be affected by the mode of administration. Therefore, the following experiments were conducted to determine the effect of the mode of administration of this compound on reproduction.

\section{MATERIALS AND METHODS}

One hundred and eighty-six mature nonparous CFN rats and ninety-six mature nonparous Taconic (Swiss Webster) mice were used in these experiments. Both rats and mice received water and a Wayne-Lab Blox ration containing $100 \mathrm{ppm}$ chlortetracycline ad libitum throughout the experiments, except the males and females on the drug-diet experiments. In the drug-diet experiments, feeding was ad libitum during the time the females were exposed to the treated diet $\left(7 \frac{1}{2} \mathrm{hr} /\right.$ day $)$, whereas the males in separate cages received the untreated diet ad libitum at the same time.

The compound when administered subcutaneously was suspended in a vehicle consisting of a $0.5 \%$ low viscosity carboxymethylcellulose in physiological saline to which $10 \%$ polyethylene glycol had been added. The vehicle used for gavage feeding was a $10 \%$ mixture of ethyl alcohol in distilled water.

Throughout the text, Group 1 refers to control females; Groups 2, 3 and 4 refer to females receiving 8,16 and $32 \mathrm{mg} / \mathrm{kg}$ of Compound I.C.I. 33,828, respectively.

In all but one experiment (Experiment 2A) females were treated with Compound I.C.I. 33,828 for a total of 15 days. During the first 4 days of treatment, females were not exposed to males. Males were placed with females for the last 11 days of treatment. Known fertile males were used throughout the experiments and in no case were males treated with the compound. In Experiment 2A, females in Groups 2, 3 and 4 received a restricted amount of the untreated diet for the 15-day treatment period. 


\section{Experiment 1. Subcutaneous injections}

Rats. Forty-eight CFN females were randomly assigned to four treatment groups (12 of /group) to study the influence of subcutaneous injection of Compound I.C.I. 33,828 on reproduction in rats. They were housed two/cage and received single daily injections of 8,16 or $32 \mathrm{mg} / \mathrm{kg}$ at 09.00 hours for 15 days. Known fertile CFN males were placed with the females ( $1 \delta^{*} / 2$ ofo ) at 11.00 hours on the 5th day of injections and remained with the females until 09.00 hours on the day following the last injection, at which time they were removed. Vaginal smears were obtained daily ( 09.00 hours) while males were caged with the females. All females were housed separately after removal of the males and examined daily ( 08.30 hours) for birth of litters. The date of birth, number of young (alive and dead) and total litter weight (live young only) were recorded for each female that littered.

Mice. Forty-eight Taconic females were randomly assigned to four treatment groups (12 of /group) to study the influence of subcutaneous injection of Compound I.C.I. 33,828 on reproduction in mice. The mice were treated as described for rats, with the following exceptions: females were housed three/ cage for the first 4 days of injections, and were then paired individually with a known fertile male for the last 11 days of injections. Daily examinations were made for vaginal plugs at 08.30 hours.

\section{Experiment 2. Drug-diet}

Rats. Forty-eight CFN females were assigned to four treatment groups (12 fo/group) to study the effect of feeding Compound I.C.I. 33,828 on reproduction in the rat. Females of uniform weight were assigned to each group and housed two/cage during pre-treatment and treatment periods. Throughout the 7-day pre-treatment period, the males and females were trained to a $7 \frac{1}{2} \mathrm{hr} /$ day feeding period; the regular laboratory diet was placed in the cage daily at 09.00 hours and removed at 16.30 hours.

The same feeding schedule was followed during the 15-day treatment period except that females in Groups 2, 3 and 4 received the drug-diet at levels of 8, 16 and $32 \mathrm{mg} / \mathrm{kg}$, respectively. Starting on the 5 th day of treatment period, the drug-diet was removed each day at 16.30 hours and known fertile CFN males were placed with the females $(10 / 2$ of $)$. The males remained with the females until 09.00 hours the following day at which time they were removed and the drug-diet returned to the cage. These procedures were followed throughout the treatment period. Vaginal smears were obtained daily while females were exposed to males. Average daily feed intake and body weights were recorded on the 1st, 6th and 11th days of the treatment period and the 1st day after treatment. The date of birth, number of young born (alive and dead) and litter weights (live young only) were recorded also. All females were housed separately after the 15-day treatment period, and received the regular laboratory diet ad libitum. Daily examinations were made for birth of new litters.

\section{Experiment 2A. Restricted feed intake of basal diet}

Rats. A reduction of feed intake was observed in the above experiments; therefore an additional forty-eight GFN females were used to determine the 
influence of restricted feed intake on reproduction in rats. The forty-eight females were randomly assigned to four treatment groups, and the same procedures were followed as described in Experiment 2, except that females in Groups 2, 3 and 4 received the regular laboratory diet during the treatment period, but at the same rate as the food consumption of females in Groups 2, 3 and 4 on the drug-diet experiment.

Mice. Forty-eight Taconic females were randomly assigned to four treatment groups (12 of /group) to determine the effects of feeding Compound I.C.I. 33,828 on reproduction in mice. The same experimental design and procedures were used with the mice as described for the drug-diet experiment in rats. Females, however, were housed three/cage during the first 4 days of the treatment period. Thereafter, females were housed individually with a male until the end of the treatment period. Daily examinations (08.30 hours) were made for vaginal plugs while the males were with the females. Body weights of the females were obtained on Days 1, 5, 10 and 15 of the treatment period.

\section{Experiment 3. Gavage feeding}

Rats. Forty-two CFN females were used to determine the effect of gavage feeding Compound I.C.I. 33,828 on reproduction in rats. Unequal numbers of females were randomly assigned to four treatment groups. Females were housed two/ cage. All females were gavage-fed once daily (between 09.00 and 11.00 hours) with either the vehicle (Group 1) or varying levels of the compound (Groups 2 to 4) for 15 days. Known fertile CFN males were placed ( $10 / 2$ of $)$ with the females at 14.00 hours on the 5 th day of gavage-feeding and remained with the females until 09.00 hours on the day following the last treatment, at which time they were removed. Following removal of the males, females were placed in individual cages and examined daily for birth of litters. Date of littering and number of young born (alive and dead) were recorded. All litters were weaned at 21 days of age. After weaning of the last litter, the original pairs of females were again housed together. Ten days later, the same males were added to the cages of the same females for 19 days. The males were then removed and the females placed in separate cages and observed daily for birth of litters. The same data were obtained for the second litter as for the first.

\section{Experiment 4. Gavage feeding}

Rats. As a result of the data collected in the previous experiments, it was necessary to determine the effect of Compound I.C.I. 33,828 on zygote development and transport during Days 1, 2, 3 and 4 of pregnancy. The day on which spermatozoa were noted in the vaginal smear was considered Day 1 of pregnancy. Two levels of the drug $(8 \mathrm{and} 16 \mathrm{mg} / \mathrm{kg}$ ) were investigated. The compound was gavage-fed daily for three consecutive days, to groups of four CFN females each, starting on Days 1, 2, 3 and 4 of pregnancy. All females were killed between 09.00 and 13.00 hours on the day following the last treatment. Thus, females were killed on Days 4, 5, 6 and 7 of pregnancy. Photographs of zygotes were made from females on the $16 \mathrm{mg} / \mathrm{kg}$ level. 


\section{RESULTS}

\section{SUBCUTANEOUS INJECTION}

Results of these experiments are presented in Tables 1 and 2. Copulation occurred in only a few Group 2 rats (Table 1) receiving Compound I.C.I. 33,828,

TABLE 1

THE INFLUENCE OF SUBCUTANEOUS INJEGTIONS OF COMPOUND I.C.I. 33,828 ON REPRODUCTION IN RATS (EXPERIMENT 1)

\begin{tabular}{c|c|c|c|c|c|c|c}
\hline $\begin{array}{c}\text { Treatment } \\
\text { group* }\end{array}$ & $\begin{array}{c}\text { Dosel } \\
\text { female/ } \\
\text { day } \\
(\text { mg } / \mathrm{kg})\end{array}$ & $\begin{array}{c}\text { No. of } \\
\text { positive } \\
\text { smears }(\dagger)\end{array}$ & $\begin{array}{c}\text { No. of } \\
\text { females } \\
\text { littering }\end{array}$ & $\begin{array}{c}\text { Average } \\
\text { litter } \\
\text { sizel } \\
\text { pregnant } \\
\text { female }\end{array}$ & $\begin{array}{c}\text { Average body } \\
\text { weight of } \\
\text { viable young } \\
(\mathrm{g})\end{array}$ & \multicolumn{2}{|c|}{$\begin{array}{c}\text { Average body weights } \\
\text { of females during } \\
\text { treatment period } \\
(\mathrm{g})\end{array}$} \\
\hline 1 & 0 & 9 & 10 & $11 \cdot 0$ & $5 \cdot 9$ & 191 & 218 \\
2 & 8 & 4 & 2 & $9 \cdot 0$ & $6 \cdot 5$ & 189 & 210 \\
3 & 16 & 0 & 0 & 0 & 0 & 189 & 191 \\
4 & 32 & 0 & 0 & 0 & 0 & 190 & 186 \\
\hline
\end{tabular}

* Twelve females/treatment group, one female killed accidentally in Group 4.

$\dagger$ Positive smear $=$ spermatozoa in vaginal smears.

whereas in mice, matings occurred in all groups (Table 2): Litters were observed in all groups of mice receiving the compound, while in rats only two females in Group 2 produced litters. The average litter size of control females in both species was slightly greater than that of females receiving Compound I.C.I. 33,828 .

TABLE 2

THE INFLUENGE OF SUBGUTANEOUS INJEGTIONS OF GOMPOUND I.C.I. 33,828 ON REPRODUCTION IN MICE (EXPERIMENT 1)

\begin{tabular}{c|c|c|c|c|c}
\hline $\begin{array}{c}\text { Treatment } \\
\text { group* }\end{array}$ & $\begin{array}{c}\text { Dosel } \\
\text { female/ } \\
\text { day } \\
\text { (mg/kg) }\end{array}$ & $\begin{array}{c}\text { No. of } \\
\text { females } \\
\text { with } \\
\text { vaginal } \\
\text { plugs }\end{array}$ & $\begin{array}{c}\text { No. of } \\
\text { females } \\
\text { littering }\end{array}$ & $\begin{array}{c}\text { Average } \\
\text { litter size } \\
\text { (littering } \\
\text { females only })\end{array}$ & $\begin{array}{c}\text { Average } \\
\text { body weight } \\
\text { of viable } \\
\text { young } \\
(\mathrm{g})\end{array}$ \\
\hline 1 & 0 & 3 & 10 & $11 \cdot 1$ & $1 \cdot 6$ \\
2 & 8 & 7 & 8 & $10 \cdot 5$ & $1 \cdot 5$ \\
3 & 16 & 4 & 10 & $10 \cdot 3$ & $1 \cdot 5$ \\
4 & 32 & 7 & 7 & $10 \cdot 4$ & $1 \cdot 5$ \\
\hline
\end{tabular}

* Twelve females/treatment group.

DRUG DIET

Feed intake was reduced in rats receiving Compound I.C.I. 33,828 in the diet (Text-fig. 1). Females consumed little, if any, of the diet during the first feeding period, which resulted in large losses in body weight (Text-fig. 2). Feed intake increased thereafter, but never returned to control levels. An experiment was designed to determine the effect of a restricted feed intake on reproduction in 


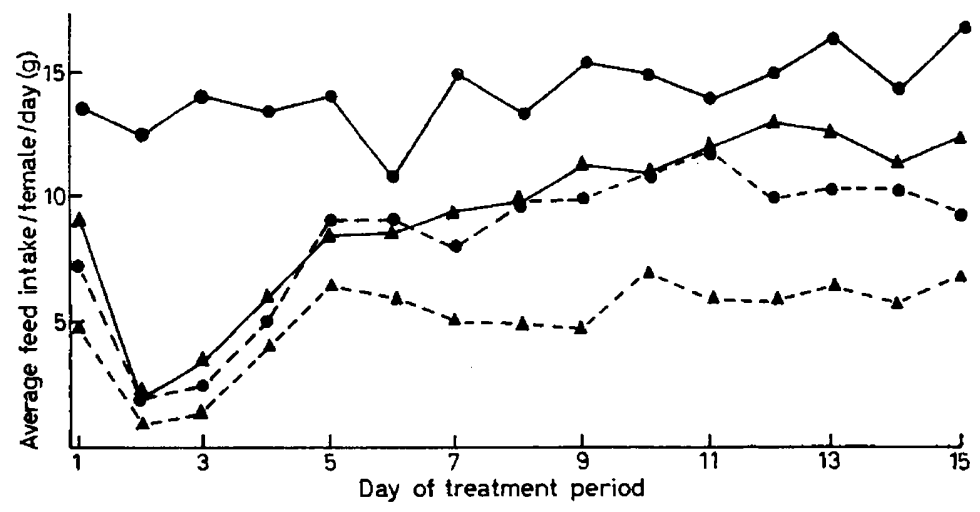

TEXT-FIG. 1. Average daily food intake of females fed Compound I.C.I. 33,828 in the diet. , Group 1; $\Delta-\Delta$, Group 2; --O, Group 3; $\Delta-\Delta$, Group 4 .

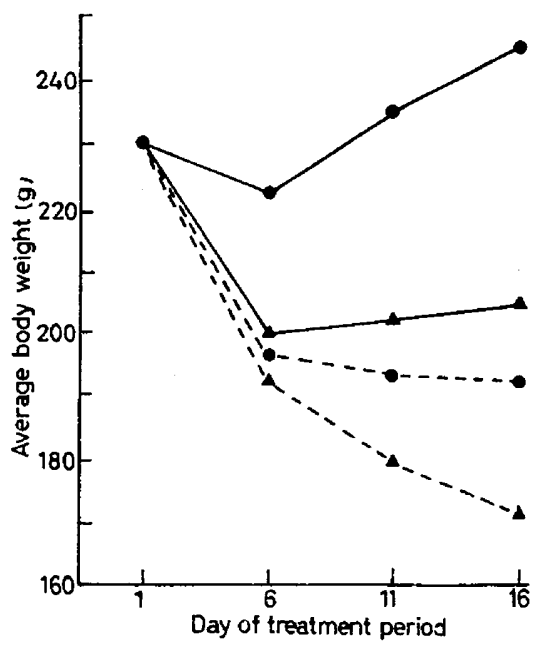

Text-FIG. 2. Average body weights of rats fed Compound I.C.I. 33,828 in the diet. $\ldots$, Group 1; $\Lambda-\Delta$, Group 2; -. Group 3; $\wedge-\Delta$, Group 4.

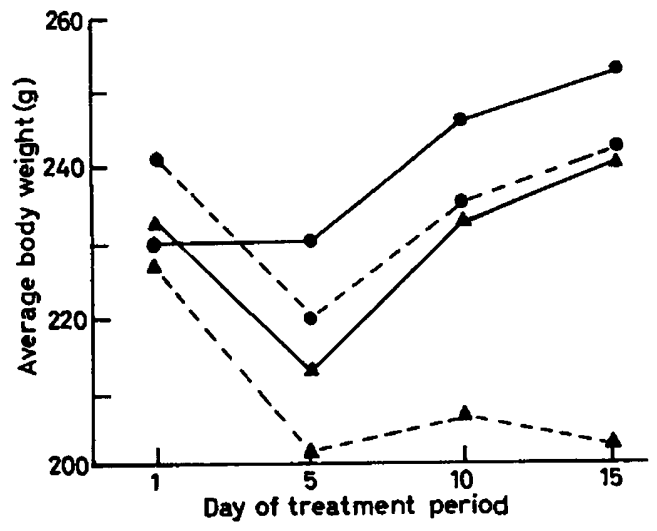

TEXT-FIG. 3. Average body weights of rats on restricted feed intake. - - Group 1; $\Lambda-\Lambda$, Group 2;.-- , Group 3 ; $\Lambda--\Lambda$, Group 4 . 


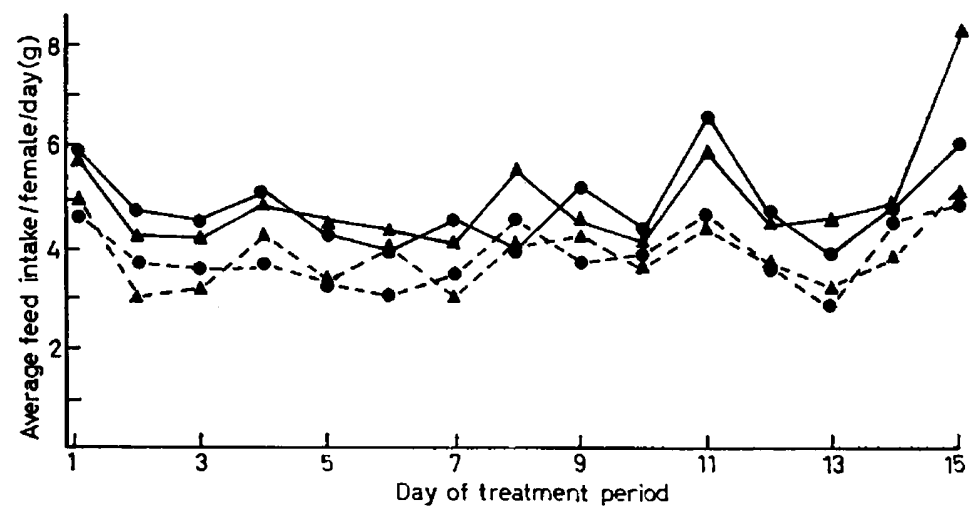

Text-FIG. 4. Average daily feed intake of mice fed Compound I.C.I. 33,828 in the diet.

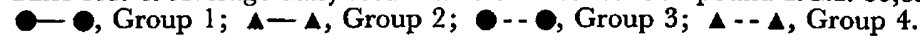

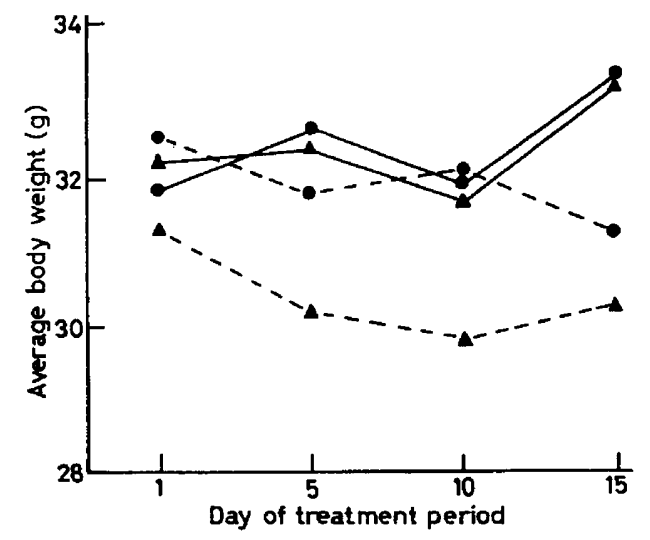

TEXT-FIG. 5. Average body weights of mice fed Compound I.C.I. 33,828 in the diet. $-\bullet$, Group 1; $\Delta-\Delta$, Group 2; -- Group 3; $\Delta-\Delta$, Group 4.

TABLE 3

THE INFLUENCE OF COMPOUND I.C.I. 33,828, WHEN FED IN THE DIET, ON REPRODUCTION IN RATS (EXPERTMENT 2)

\begin{tabular}{|c|c|c|c|c|c|c|c|c|}
\hline \multirow{2}{*}{$\begin{array}{l}\text { Treatment } \\
\text { group }\end{array}$} & \multicolumn{2}{|c|}{$\begin{array}{l}\text { Dose/female/day } \\
(\mathrm{mg} / \mathrm{kg})\end{array}$} & \multirow{2}{*}{$\begin{array}{c}\text { No. of } \\
\text { positive } \\
\text { smears }\end{array}$} & \multirow{2}{*}{$\begin{array}{l}\text { No. of } \\
\text { females } \\
\text { littering }\end{array}$} & \multicolumn{2}{|c|}{$\begin{array}{l}\text { Total No. of } \\
\text { young born }\end{array}$} & \multirow{2}{*}{$\begin{array}{l}\text { Average } \\
\text { litter } \\
\text { sizel } \\
\text { pregnant } \\
\text { female }\end{array}$} & \multirow{2}{*}{$\begin{array}{l}\text { Average } \\
\text { body weight } \\
\text { of viable } \\
\text { young } \\
(g)\end{array}$} \\
\hline & Designed & Actual & & & Alive & Dead & & \\
\hline $\begin{array}{l}1 \\
2 \\
3 \\
4\end{array}$ & $\begin{array}{r}0 \\
8 \\
16 \\
32\end{array}$ & $\begin{array}{l}0 \\
6 \cdot 4 \\
12 \cdot 0 \\
16 \cdot 0\end{array}$ & $\begin{array}{r}10 \\
2 \\
3 \\
0\end{array}$ & $\begin{array}{r}10 \\
0 \\
0 \\
0\end{array}$ & $\begin{array}{r}101 \\
0 \\
0 \\
0\end{array}$ & $\begin{array}{l}2 \\
0 \\
0 \\
0\end{array}$ & $\begin{array}{c}10 \cdot 1 \\
0 \\
0 \\
0\end{array}$ & $\begin{array}{l}5 \cdot 7 \dagger \\
0 \\
0 \\
0\end{array}$ \\
\hline
\end{tabular}

* Twelve females/treatment group, one female died during the treatment period in Group 3.

$\dagger$ Viable foetuses only. 
TABLE 4

THE INFLUENCE OF RESTRICTED FEED INTAKE ON REPRODUCTION IN RATS (EXPERIMENT 2A)

\begin{tabular}{|c|c|c|c|c|c|c|}
\hline \multirow{2}{*}{$\begin{array}{c}\text { Treatment } \\
\text { group* }\end{array}$} & \multirow{2}{*}{$\begin{array}{c}\text { Fed at rate } \\
\text { equiv. to } \\
\text { female rats } \\
\text { on drug-diet } \\
\text { (mg/kg) }\end{array}$} & \multirow{2}{*}{$\begin{array}{l}\text { No. of } \\
\text { positive } \\
\text { smears }\end{array}$} & \multirow{2}{*}{$\begin{array}{l}\text { No. of } \\
\text { females } \\
\text { littering }\end{array}$} & \multicolumn{2}{|c|}{$\begin{array}{l}\text { Total No. of } \\
\text { young born }\end{array}$} & \multirow{2}{*}{$\begin{array}{c}\text { Average litter } \\
\text { size/ } \\
\text { pregnant } \\
\text { female (viable } \\
\text { young only) }\end{array}$} \\
\hline & & & & Alive & Dead & \\
\hline $\begin{array}{l}1 \\
2 \\
3 \\
4\end{array}$ & $\begin{array}{r}0 \\
8 \\
16 \\
32\end{array}$ & $\begin{array}{l}6 \\
4 \\
8 \\
7\end{array}$ & $\begin{array}{l}5 \\
4 \\
8 \\
8 \dagger\end{array}$ & $\begin{array}{l}67 \\
39 \\
68 \\
44\end{array}$ & $\begin{array}{r}1 \\
0 \\
11 \\
5\end{array}$ & $\begin{array}{c}13 \cdot 4 \\
9 \cdot 8 \\
8 \cdot 5 \\
6 \cdot 3 \ddagger\end{array}$ \\
\hline
\end{tabular}

* Twelve females/treatment group.

Data for one female that littered not recorded.

$\$$ Average based on seven females for which data were available.

TABLE 5

THE INFLUENCE OF COMPOUND 1.C.I. 33,838, WHEN FED IN THE DIET, ON REPRODUCTION IN MICE (EXPERIMENT 2)

\begin{tabular}{|c|c|c|c|c|c|c|c|}
\hline \multirow{2}{*}{$\begin{array}{c}\text { Treatment } \\
\text { group* }\end{array}$} & \multirow{2}{*}{$\begin{array}{c}\text { Dosel } \\
\text { femalel } \\
\text { day } \\
(\mathrm{mg} / \mathrm{kg})\end{array}$} & \multirow{2}{*}{$\begin{array}{c}\text { No. of } \\
\text { females } \\
\text { with } \\
\text { vaginal } \\
\text { plugs }\end{array}$} & \multirow{2}{*}{$\begin{array}{l}\text { No. of } \\
\text { females } \\
\text { littering }\end{array}$} & \multicolumn{2}{|c|}{$\begin{array}{l}\text { Total No. of } \\
\text { young born }\end{array}$} & \multirow{2}{*}{$\begin{array}{c}\text { Average } \\
\text { litter sizel } \\
\text { pregnant } \\
\text { female (live } \\
\text { young only) }\end{array}$} & \multirow{2}{*}{$\begin{array}{c}\text { Average } \\
\text { body weight } \\
\text { viable } \\
\text { young }(g)\end{array}$} \\
\hline & & & & Alive & Dead & & \\
\hline $\begin{array}{l}1 \\
2 \\
3 \\
4\end{array}$ & $\begin{array}{r}0 \\
8 \\
16 \\
32\end{array}$ & $\begin{array}{l}7 \\
4 \\
5 \\
2\end{array}$ & $\begin{array}{l}7 \\
8 \\
4 \dagger \\
0\end{array}$ & $\begin{array}{l}77 \\
75 \\
15 \dagger \\
0\end{array}$ & $\begin{array}{l}2 \\
2 \\
2 \\
0\end{array}$ & $\begin{array}{c}11 \cdot 0 \\
9 \cdot 4 \\
3 \cdot 8 \ddagger \\
0\end{array}$ & $\begin{array}{l}1.5 \\
1.6 \\
1.75 \\
0\end{array}$ \\
\hline
\end{tabular}

* Twelve females/treatment group; one female in Group 3 died 12 days after treatment withdrawal.

$\dagger$ Two viable foetuses found when one female was autopsied.

I Average litter size includes two viable foetuses not born.

$\S$ Average body weight does not include the two viable unborn foetuses.

\section{TABLE 6}

THE INFLUENGE OF THE GAVAGE FEEDING OF COMPOUND I.C.I, 33,828 ON REPRODUCTION IN THE RAT (EXPERIMENT 3)

\begin{tabular}{|c|c|c|c|c|c|}
\hline \multirow{2}{*}{$\begin{array}{l}\text { Treatment } \\
\text { group* }\end{array}$} & \multirow{2}{*}{$\begin{array}{c}\text { Dosel } \\
\text { female/day } \\
(\mathrm{mg} / \mathrm{kg})\end{array}$} & \multicolumn{2}{|c|}{$\begin{array}{l}\text { No. of } \\
\text { females littering }\end{array}$} & \multicolumn{2}{|c|}{$\begin{array}{c}\text { Mean litter size } \\
\text { (live foetuses) }\end{array}$} \\
\hline & & Litter 1 & Litter 2 & Litter 1 & Litter 2 \\
\hline $\begin{array}{l}1 \dagger \\
2 \\
3 \\
4\end{array}$ & $\begin{array}{r}0 \\
8 \\
16 \\
32\end{array}$ & $\begin{array}{l}9 \\
2 \\
0 \\
0\end{array}$ & $\begin{array}{r}9 \\
7 \\
8 \\
12\end{array}$ & $\begin{array}{l}7 \cdot 9 \\
3 \cdot 5 \\
0 \\
0\end{array}$ & $\begin{array}{r}9.7 \\
11.0 \\
11.9 \\
9.8\end{array}$ \\
\hline
\end{tabular}

* Thirteen females in treatment Groups 1 and 4, nine females in treatment Groups 2 and 3.

$\uparrow$ Two females in Group 1 died during the treatment period. 
TABLE 7

LOCATION AND CLEAVAGE STATE OF OVA FOLLOWING TREATMENT WTTH COMPOUND I.C.I. 33,828 FOR 3 CONSECUTIVE DAYS (EXPERIMENT 4)

\begin{tabular}{|c|c|c|c|c|c|c|c|}
\hline \multirow{2}{*}{$\begin{array}{c}\text { Dose } \\
(m g / k g)\end{array}$} & \multirow{2}{*}{$\begin{array}{l}\text { Day of } \\
\text { pregnancy } \\
\text { females } \\
\text { killed }\end{array}$} & \multirow{2}{*}{$\begin{array}{c}\text { Female } \\
\text { No. }\end{array}$} & \multirow{2}{*}{$\begin{array}{l}\text { Location } \\
\text { of ova }\end{array}$} & \multicolumn{3}{|c|}{ Condition of zygotes } & \multirow[t]{2}{*}{ Developmental stage of zygotes } \\
\hline & & & & Normal & Abnormal & Total & \\
\hline 8 & 4 & $\begin{array}{l}10 \\
22 \\
27^{*} \\
10 \mathrm{~A}\end{array}$ & $\begin{array}{l}\text { Oviducts } \\
\text { Oviducts } \\
\text { Uteri } \\
\text { Oviducts }\end{array}$ & $\begin{array}{r}8 \\
15 \\
8 \\
8\end{array}$ & $\begin{array}{l}6 \\
0 \\
0 \\
1\end{array}$ & $\begin{array}{r}14 \\
15 \\
8 \\
9\end{array}$ & $\begin{array}{l}\text { 3-6-cell stage } \\
\text { 8-cell stage } \\
\text { Implantation sites } \\
\text { 4-cell stage }\end{array}$ \\
\hline 8 & 5 & $\begin{array}{l}32 \\
21 \\
12 \\
35\end{array}$ & $\begin{array}{l}\text { Uteri } \\
\text { Uteri } \\
\text { Uteri } \\
\text { Uteri }\end{array}$ & $\begin{array}{r}3 \\
14 \\
11 \\
6\end{array}$ & $\begin{array}{l}5 \\
0 \\
0 \\
0\end{array}$ & $\begin{array}{r}8 \\
14 \\
11 \\
6\end{array}$ & $\begin{array}{l}\text { Blastocysts in zona } \\
\text { Morulae, blastocysts in zona } \\
\text { Morulae, blastocysts in zona } \\
\text { Morulae, blastocysts in zona }\end{array}$ \\
\hline 8 & 6 & $\begin{array}{r}3 \\
25 \\
15 \\
31\end{array}$ & $\begin{array}{l}\text { Uteri } \\
\text { Uteri } \\
\text { Uteri } \\
\text { Uteri }\end{array}$ & $\begin{array}{r}11 \\
11 \\
6 \\
0\end{array}$ & $\begin{array}{l}0 \\
0 \\
0 \\
0\end{array}$ & $\begin{array}{r}11 \\
11 \\
6 \\
0\end{array}$ & $\begin{array}{l}\text { Blastocysts outside zona } \\
\text { Blastocysts outside zona } \\
\text { Six blastocysts outside zona } \\
\text { Eight ovulation points on ovaries }\end{array}$ \\
\hline 8 & 7 & $\begin{array}{r}6 \\
13 \\
30 \\
7\end{array}$ & $\begin{array}{l}\text { Uteri } \\
\text { Uteri } \\
\text { Uteri } \\
\text { Uteri }\end{array}$ & $\begin{array}{r}12 \\
11 \\
9 \\
15\end{array}$ & $\begin{array}{l}0 \\
0 \\
0 \\
0\end{array}$ & $\begin{array}{r}12 \\
11 \\
9 \\
15\end{array}$ & $\begin{array}{l}\text { Implantation sites } \\
\text { Implantation sites } \\
\text { Implantation sites } \\
\text { Implantation sites }\end{array}$ \\
\hline 16 & 4 & $\begin{array}{l}26 \\
5 \\
5 \mathrm{~A} \\
4\end{array}$ & $\begin{array}{l}\text { Oviducts } \\
\text { Oviducts } \\
\text { Oviducts } \\
\text { Oviducts }\end{array}$ & $\begin{array}{r}14 \\
0 \\
11 \\
16\end{array}$ & $\begin{array}{r}2 \\
13 \\
0 \\
0\end{array}$ & $\begin{array}{l}16 \\
13 \\
11 \\
16\end{array}$ & $\begin{array}{l}\text { 8-cell stage } \\
\text { Fertilized fragmented } \\
\text { 4-8-cell stage } \\
\text { 8-cell stage }\end{array}$ \\
\hline 16 & 5 & $\begin{array}{c}2 \\
34 \\
9 \mathrm{~A} \\
12 \mathrm{~A}\end{array}$ & $\begin{array}{l}\text { Uteri } \\
\text { Uteri } \\
\text { Uteri } \\
\text { Uteri }\end{array}$ & $\begin{array}{r}14 \\
10 \\
10 \\
6\end{array}$ & $\begin{array}{l}0 \\
0 \\
0 \\
0\end{array}$ & $\begin{array}{r}14 \\
10 \\
10 \\
6\end{array}$ & $\begin{array}{l}\text { Morulae, blastocysts in zona } \\
\text { Morulae, blastocysts in zona } \\
\text { Blastocysts inside, outside zona } \\
\text { Morulae, blastocysts in zona }\end{array}$ \\
\hline 16 & 6 & $\begin{array}{l}28 \\
11 \dagger \\
18 \\
29\end{array}$ & $\begin{array}{l}\text { Uteri } \\
\text { Uteri } \\
\text { Uteri } \\
\text { Uteri }\end{array}$ & $\begin{array}{r}9 \\
6 \\
10 \\
12\end{array}$ & $\begin{array}{l}0 \\
0 \\
0 \\
0\end{array}$ & $\begin{array}{r}9 \\
6 \\
10 \\
12\end{array}$ & $\begin{array}{l}\text { Blastocysts outside zona } \\
\text { Blastocysts outside zona } \\
\text { Blastocysts outside zona } \\
\text { Blastocysts in zona }\end{array}$ \\
\hline 16 & 7 & $\begin{array}{l}23 \\
20 \\
16 \\
36\end{array}$ & $\begin{array}{l}\text { Uteri } \\
\text { Uteri } \\
\text { Uteri } \\
\text { Uteri }\end{array}$ & $\begin{array}{r}13 \\
14 \\
15 \\
5\end{array}$ & & $\begin{array}{r}13 \\
14 \\
15 \\
5\end{array}$ & $\begin{array}{l}\text { Implantation sites } \\
\text { Implantation sites } \\
\text { Implantation sites } \\
\text { Implantation sites }\end{array}$ \\
\hline
\end{tabular}

* Female killed on Day 7 pregnancy.

$\dagger$ Uteri on one side discarded prior to flushing. 
rats. The effects of a restricted feed intake on body weights are presented in Text-fig. 3.

The effects of adding this compound to the diet of mice were not as pronounced as in rats. Though feed intake was slightly less for Groups 2 and 3 (Text-fig. 4) throughout the course of the experiment, the losses in body weight were not great (Text-fig. 5).

Table 3 shows the effects on reproduction when Compound I.C.I. 33,828 was added to the diet of rats. Matings occurred in Group 2 and 3 females, but no litters were produced by these females. The results of feeding a restricted amount of the control diet (Table 4) illustrate that the foregoing results (Table 3) were not attributable entirely to a reduced feed intake.

Matings were observed in all groups of mice receiving Compound I.C.I. 33,828 in the diet (Table 5). However, litters were not produced by Group 4 females. Litter size in mice was directly affected by the concentration of this compound in the diet.

\section{GAVAGE FEEDING}

The results obtained when females were gavage-fed with Compound I.C.I. 33,828 are presented in Table 6. In rats, only two females (Group 2) receiving the compound produced litters; moreover, these were approximately half the size of those produced by control females (Group 1). Subsequent to the weaning of the two Group 2 litters, normal fertility was restored in all groups of females that received the compound.

Gavage-feeding females in the early stages of pregnancy with either 8 or 16 $\mathrm{mg} / \mathrm{kg}$ did not inhibit normal development or alter the time at which zygotes entered the uterus. These results are presented in Table 7. Zygotes in the 4- to 8-cell stage (Pl. 1, Fig. 1) were recovered from the oviducts on Day 4 of pregnancy (Day $1=$ day spermatozoa observed in the vaginal smear). Normally developing morulae and blastocysts (in zona pellucida) were recovered from the uteri of females killed on Day 5 of pregnancy (Pl. 1, Fig. 2). Blastocysts, generally outside the zona pellucida but freely floating, were recovered from the uteri of females killed on Day 6 of pregnancy (Pl. 1, Fig. 3). These results suggest a delay in implantation of about $24 \mathrm{hr}$. Females killed on Day 7 of pregnancy contained implantation sites (Pl. 1, Fig. 4).

\section{DISCUSSION}

The results of these experiments clearly show that differences exist in the reproductive performance of rats and mice treated with Compound I.C.I. 33,828 . Furthermore, the route of administration was found to be an important consideration influencing both the control of the oestrous cycle and antifertility effect of the compound. The route of administration was more important in mice than in rats. Administration of the compound resulted in a loss of body weight in rats, which was most pronounced in the drug-diet experiment. Similar losses were noted in mice, but to a lesser extent. Patchy losses of hair were noted in some rats and mice; this observation is in agreement with that of 


\section{P'LATE 1}
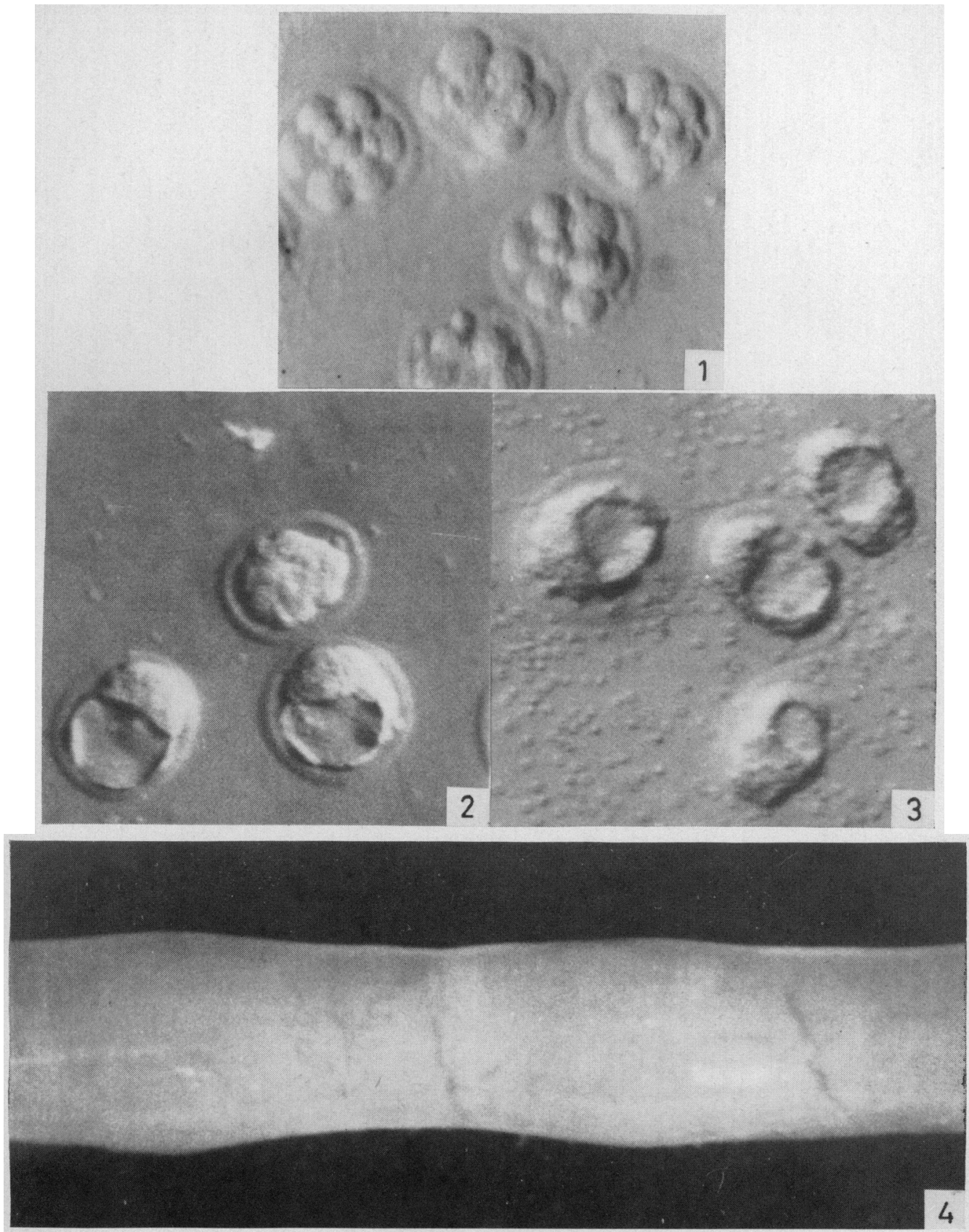

Fig. 1. Eight-celled zygotes recovered from oviducts on Day 4 of pregnancy. $\times 400$.

lig. 2. Morula and blastocysts recovered from uteri on Day 5 of pregnancy. $\times 400$.

FIG. 3. Blastocysts recovered from uteri on Day 6 of pregnancy. $\times 400$.

lig. 4. Implantation sites noted on Day 7 of pregnancy. $\times 6$.

(Facing p. 82) 
Paget et al. (1961). No deaths could be attributed to treatment with the compound. Paget et al. (1961) stated that daily oral (gavage) doses of Compound I.C.I. 33,828 as low as $16 \mathrm{mg} / \mathrm{kg}$ affect reproduction in rats. The results of our experiments with rats confirm this finding and show that pregnancy is prevented with doses as low as $16 \mathrm{mg} / \mathrm{kg}$, whether administered orally or subcutaneously. Oral dosing appears to be somewhat more effective and this finding is in general agreement with that of Edgren \& Peterson (1964).

Paget et al. (1961) also suggested that in the early stages of pregnancy in the rat, Compound I.C.I. 33,828 may prevent implantation. Harper (1964) presented evidence showing that doses of $100 \mathrm{mg} / \mathrm{kg}$ for 3 successive days did not prevent implantation except when treatment was initiated on Day 2 of pregnancy. The results of our experiment (Experiment 4), though not directly comparable, are interpreted as confirming, in general, Harper's observations. However, in our experiment, when treatment was initiated on Day 2 of pregnancy, normally-developing zygotes were recovered on Day 5 of pregnancy and normal implantation sites were observed on Day 7 of pregnancy. These results are in conflict with those of Harper (1964) and should, perhaps, be re-examined because of the discrepancy. Harper (1964) also suggested that it was unlikely that the compound had a direct effect on the metabolism of the developing zygotes. Our results indirectly lend support to this statement. Two levels of Compound I.C.I. 33,828, 8 and $16 \mathrm{mg} / \mathrm{kg}$, did not effect normal cell cleavage, suggesting a normal metabolism of the zygote.

In one of the experiments reported in this paper, an antifertility effect was shown when Compound I.C.I. 33,828 was added to the diet of mice. This appears to be the first experiment to show such an effect in mice. Brown (1963) observed a significant decline in ovarian and uterine weights of mice injected subcutaneously, but the dose used by Brown was approximately four times greater than the maximum dose used in these experiments. This difference in dose rate suggests the response is dose-related and that fertility may have been prevented in mice given the higher dose by subcutaneous injection. This seems not unlikely in view of the results obtained in the drug-diet study (Table 5). Thus, a dose approximately $2 \cdot 5$ times greater than the effective dose of 32 $\mathrm{mg} / \mathrm{kg}$ in the drug-diet study may be the minimum dose necessary to prevent pregnancy when injected subcutaneously. The work of Edgren \& Peterson (1964) supports this thesis.

It is concluded that Compound I.C.I. 33,828, depending on dose rate, inhibited the oestrous cycle in rats regardless of route of administration. Given either orally or subcutaneously to rats, it was also an effective antifertility agent. In mice, however, it was an effective antifertility agent only when added to the diet. The compound appeared to have no effect on the developing zygotes during the early stages of pregnancy and failed to prevent implantation. Although the present experiments were not designed to determine the mode of action of Compound I.C.I. 33,828, the results support the suggestion of other workers that gonadotrophins are, in some way, inhibited. Since the level of compound necessary for inhibition of the oestrous cycle is somewhat greater than that necessary for antifertility effects, it appears that the compound may also have an effect on the uterus after the early stages of implantation. 


\section{REFERENCES}

Bell, E. T., Brown, J. B., Fotherby, K. \& Loraine, J. A. (1962) Effect of a derivative of dithiocarbamoylhydrazine on hormone excretion during the menstrual cycle. Lancet, ii, 528.

Brown, P. S. (1963) Observations on a dithiocarbamoylhydrazine as an inhibitor of pituitary gonadotrophic activity. F. Endocr. 26, 425.

Edgren, R. A. \& Peterson, D. L. (1964) Blockage of ovarian compensatory hypertrophy in hemicastrated rats with a dithiocarbamoylhydrazine derivative. $\mathcal{F}$. Endocr. 30, 399.

France, R. A. \& Pincus, G. (1964) Biologically active substances affecting gonadotrophin induced ovulation in immature rats. Endocrinology, 75, 359.

HARPER, M.J. K. (1964) Effects of 1-alpha-methylallylthiocarbamoyl-2-methylthiocarbamoylhydrazine (I.C.I. 33,828) on early pregnancy in the rat. F. Reprod. Fert. 7, 211.

MeArs, R. (1962) The effect of a derivative of dithiocarbamoyl-hydrazine during the menstrual cycle. Lancet, $\mathbf{i i}, 614$.

Paget, G. E., Walpole, A. L. \& Richardson, D. N. (1961) Non-steroid inhibitors of pituitary gonadotrophic function. Nature, Lond. 192, 1191. 